\title{
The Strength of Audits, Reporting Standards and Corruption, on Tax Evasion: A Cross-Country Study
}

\author{
Raga Hudori $^{1}$, Elia Mustikasari ${ }^{2}$
}

\begin{abstract}
:
Purpose: The study aims to examine the influence of audits, reporting standards and corruption on tax evasion on selected countries.

Design/Methodology/Approach: Tax evasion is measured using the shadow economy estimation and a tax evasion survey from the IMD World Competitiveness Yearbook by using a sample of 132 countries in th eperiod 2008-2015. Data were analyzed using Ordinary Least Square regression $(O L S)$ and multilevel mediation analysis.

Findings: The results showed that improving audit quality and reporting standards reducing the level of corruption can significantly reduce tax evasion. We also find that corruption mediates the effect of the strength of audit and reporting standards on tax evasion.

Practical Implications: Result implies that in order to reduce tax evasion, the government must reduce the level of corruption first through strengthening audits and reporting standards. At the end, it is hoped that no more corrupted officials will facilitate the company to manipulate financial statements.

Originality/Value: This research provides a clearer view by building a conceptual framework on how corruption mediates the effect of audit power and reporting standards on tax evasion.
\end{abstract}

Keywords: Strength of audit and reporting standards, corruption, tax evasion.

JEL Codes: H26, M48, D73.

Paper Type: Research article.

\footnotetext{
${ }^{1}$ Universitas Airlangga, Department of Accounting,

e-mail: raga.hudori-2018@feb.unair.ac.id

${ }^{2}$ Universitas Airlangga, Department of Accounting,

e-mail: elia-m@feb.unair.ac.id
} 


\section{Introduction}

Tax avoidance, tax aggressiveness, and tax evasion are widespread phenomena and are the reason for several financial scandals in developed and developing countries, $t$ significantly affecting fiscal revenues due to lack of tax compliance and weak auditing systems (Dreher and Schneider, 2010; Picur and Riahi-Belkaoui, 2006). Tax aggressiveness and tax evasion are often associated with unethical actions such as corruption, shadow economy, and income shifting. Thia is the reason why the Government has an interest in understanding the causes of tax evasion and trying to reduce the level of tax evasion in the community (Richardson, 2008).

According to Global Financial Integrity (GFI) every year there are about \$ 1 trillion illegal flows in developing and developed countries because of fiscal crime, corruption, and tax evasion. In addition, based on the estimation results from Medina and Schneider (2018) on the level of the shadow economy in the world the average level of the shadow economy of the world is $31.77 \%$ of total GDP. The phenomenon of tax evasion through shadow economy and corruption activities has caused developing countries to be severely disadvantaged because the state revenue obtained is smaller than the potential income that can be achieved. This causes developing countries to try to reduce the phenomenon of tax evasion without any regard to the phenomenon of corruption, even though the phenomenon of corruption itself is the cause of high tax evasion (Amoh and Nakyea, 2018).

We believe that this research is important for several reasons. First, it is still unclear how the influence of audit quality, reporting standards and corruption will affect tax evasion. Several studies suggest that the government tries to reduce the level of corruption by reducing the level of tax evasion (Alm et al., 2016; Goel and Saunoris, 2014). This is because corrupted officials can facilitate tax evasion. When a company has to pay a bribe to a corrupted official, the company will make high tax evasion by manipulating its income in exchange for the bribe costs that has been incurred to the corrupted official (Brasoveanu and Brasoveanu, 2009). However, several other studies suggest strengthening the accounting and auditing regulations to reduce tax evasion. Increased institutional transparency through better disclosure of information can be used as a means for comparison between companies. If regulations are weak, companies can choose not to disclose information or manipulate it (Maria and Nasca, 2018). Therefore, our research aims to provide a clearer view of the influence between audit quality and reporting standards, corruption, on tax evasion.

Second, our research builds a conceptual framework on how corruption mediates the effect of strength of audit and reporting standards on tax evasion, where no prior research has done that. Third, our study uses measurements of audit quality and reporting, and tax evasion that is better than in previous research. Some previous studies used the measurement of the number of auditors per capita to measure audit quality, where the measurement did not measure quality but only measured market 
demand. Instead, we use the strength of audit and reporting standards measurements from the WEF Global Competitiveness Report which measures perceptions of audit quality and reporting from executive surveys. For tax evasion, our study uses two measurements to test the consistency of results on our research estimates. First is the estimation results from Medina and Schneider (2018) which measures the level of shadow economy using a macro approach with the MIMIC model method. Second, for measurement with a micro approach we use the results of a survey on state tax evasion published by the IMD World Competitiveness Yearbook.

Next, we test our hypothesis using ordinary least square regression (OLS) and multilevel mediation analysis. Our first model shows that improving audit quality and reporting standards and reducing corruption levels can significantly reduce tax evasion. We also examine how corruption mediates the relationship between strength of audit and reporting standards on tax evasion. Interestingly, we find that the indirect effect between audit quality and reporting standards on tax evasion is greater than the direct effect. This indicates that policies to reduce tax evasion should focus on strengthening the quality of audits and reporting aimed at reducing corruption. A business environment free of corruption will minimize the potential for tax evasion.

\section{Literature Review and Hypothesis Development}

Measurement of tax evasion using shadow economy has been widely used by several studies (Amara and Khlif, 2018; Cebula, 1997; Khlif and Guidara, 2018). According to Smith (1994), shadow economy is the production of goods and services both legal and illegal that are missed from the calculation of Gross Domestic Product (GDP). Furthermore, Torgler and Schneider, (2007) explained that the shadow economy is the production of goods and services that are legal but deliberately traded in private with the excuse of avoiding tax payments and avoiding to establish administrative procedures. Several studies have discussed the role of auditing and financial reporting on tax evasion. Cebula (1997) examined how in the impact of audit probability on the level of tax evasion in the United States, and found that the level of tax evasion would decrease with increasing audit probability and penalty. A tax audit is very important because a taxpayer decides how much income to self-report based on the possibility of detection and penalties for tax evasion (Auerbach et al., 2011; Suryanto et al., 2017; Suryanto and Thalassinos, 2017).

Debacker et al. (2018) examined the impact of law enforcement in the tax sector on subsequent compliance behavior by taxpayers, and found that auditing would change taxpayer compliance behavior for the better. There are three main effects due to a tax audit. First, there is an increase in income directly when the auditor discovers noncompliance. Second, audited taxpayers tend to report higher taxable income in subsequent years because of the deterrent effect directly (D'Agosto et al., 2018; Debacker et al., 2018). Third, the indirect deterrent effect on unaudited taxpayers (Alm and Yunus, 2009). D'Agosto et al. (2018) added that soft and deep audits are 
audits that most influence reporting compliance behavior. Soft audits are considered to aim at increasing morale of taxpayer compliance better, while in-depth audits aim at recovering tax revenue (Pasekova et al., 2019).

Auerbach et al. (2011) state that low tax evasion is not because taxpayers do not want to cheat, but because they do not succeed in cheating due of the widespread use of third-party reporting, so law enforcement in the area of strict taxation is a far more effective tool to combat tax evasion rather than cutting marginal tax rates. The company is oriented towards the application of accounting and fiscal regulations in terms of presenting economic activities (Vokshi, 2018). Thus, it is important to make good accounting and auditing regulations to increase institutional transparency through better disclosure of information and can be used as a means for making comparisons between companies easier. If regulations are weak, companies can choose not to disclose information or manipulate it (Maria and Nasca, 2018). Furthermore, Khlif and Guidara (2018) suggest that good quality accountants are needed as a means to promote transparency and ethical action, comply with tax regulations and invite their clients to avoid tax evasion practices. Based on the discussion carried out above, this research hypothesizes the following:

Hypothesis 1: The strength of audit and reporting standards negatively affect tax evasion.

Several previous studies have discussed how corruption affects tax evasion. Ghura (1998) examined the level of economic policy and the impact of corruption on tax revenues and GDP. This study covers 39 African countries for the period 1985-1996. The results show that there is a negative influence between corruption and income from tax, which means that the more corrupt practices of a country will increase tax evasion. Brasoveanu dan Brasoveanu (2009) analyzed the correlation between tax revenues and corruption among 27 European Union (EU) member-states, for the period 1995-2008. The results showed that there was a negative correlation between tax burden and corruption. The same result was also confirmed by Amoh and AliNakyea (2019) which showed that corrupt activities significantly caused tax evasion activities in Ghana.

High levels of official corruption can facilitate companies to carry out tax evasion (Alm et al., 2016; Goel and Saunoris, 2014). Corruption and tax compliance are complementary (Dreher and Schneider, 2010). Corruption enables tax evasion by making it easier for taxpayers to hide their income, while tax evasion can contribute to corruption by creating additional opportunities for corruption to develop (Alm et al., 2016).

When companies have to pay bribes to corrupt officials, the company will avoid high taxes by manipulating its income in exchange for bribes that have been incurred to corrupted officials (Brasoveanu and Brasoveanu, 2009). When the company decides to avoid tax, the company will face the risk of punishment and detection 
through auditing. That makes companies to have no legal rights, so corruption can mitigate these risks by bribing corrupted officials to act as law enforcers (Goel and Saunoris, 2014). In addition, Amara and Khlif (2018) added that high levels of corruption could form a favorable environment for the development of financial crime in the form of illegal economic activities which would result in higher tax evasion.

Picur and Riahi-Belkaoui (2006) conducted empirical research from 30 developed and developing countries, the results showed that the highest tax compliance in a country was marked by high control of corruption and low bureaucracy. Prevention to improve tax compliance is to create a moral or tax climate, where citizens are protected from official corruption. High levels of corruption can reduce the tendency of individuals in certain countries to trust and comply with each government regulation, especially tax regulations (Khlif et al., 2016). Based on the discussion carried out above, this research hypothesizes the following:

\section{Hypothesis 2: The level of corruption has a negative effect on tax evasion.}

Several studies have discussed the influence between audit quality and financial reporting and the level of corruption in a country. Kimbro (2002) examined the effect of economic, institutional and cultural variables on corruption. The author concludes that good accounting can improve perceptions of corruption. Wu (2005) examined the influence between corporate accounting practices and corruption. In this study, accounting information standards are used as indicators of corporate governance. The author concludes that better accounting practices can help reduce corruption.

Malagueño et al. (2010) examined the influence between perceived levels of corruption and the quality of accounting and auditing. The results showed that the quality of accounting and auditing had a negative and significant effect on the level of corruption's perception. Countries can reduce the level of perceived corruption by increasing accounting and auditing standards to provide transparency in financial reporting (Rupeika-Apoga et al., 2018). Furthermore, Houqe and Monem (2013) examined the role of accounting information in reducing corruption using data covering 166 countries during the 1996-2011 period. The results show that countries willing to reduce corruption must improve the quality of accounting standards.

Good accounting quality can reduce corruption through better disclosure on every economic transaction (Houqe and Monem, 2013; Kimbro, 2002; Malagueño et al., 2010). Public policies that target the improvement of corporate accounting practices can be an effective anti-corruption strategy. Good accounting practices can protect companies from company costs associated with errors in reporting financial information, provide better growth prospects for companies, and eliminate costs in paying bribes (Wu, 2005). Furthermore, Wu (2005) explains that better accounting practices can reduce bribery by: 1) solving information asymmetry problems in 
companies; 2) increase the risk of detection of corrupt officials when they want to bribe; 3) limit "big corruption" in contractual agreements, concessions and privatization.

Corruption is a financial crime in general, corruption arises because it is facilitated by secrecy and lack of transparency in government (Strîmbu and González, 2018). Corruption is usually in the form of financial payments in the form of bribes, fraud, or theft which involve companies and private individuals. Kimbro (2002) has emphasized the important role of auditors and the accounting system, the auditor's function must be expanded for prevention, as well as detecting fraud. Accountants, through internal and external audits, check whether the financial statements meet national accounting standards. In addition, a good accounting system can be used to detect corrupt activities.

Governments that seek to reduce tax evasion must first ensure that the country's tax administration is honest and free of corruption (Alm et al., 2016). Good institutional quality can reduce corruption (Dreher et al., 2009). The strength of audits and reporting standards reflects the quality of institutional governance and legal force in a country. According to Houqe and Monem (2013), high-quality accounting information is not only the result of good accounting standards, but also a number of other factors such as, the rule of law, and the power of law enforcement. Policies that strengthen governance through strengthening audit quality and reporting can be tools to control corruption and the shadow economy (Goel and Saunoris, 2014). So it is quite clear that to reduce tax evasion the government must reduce the level of corruption first. Law enforcement policies such as policies to strengthen audits and reporting standards can be a means to reduce corruption. Based on the discussion carried out above, this research hypothesizes the following:

Hypothesis 3: Corruption mediates the effects of the strength of audit and reporting standards on tax evasion.

\section{Data and Research Methods}

This study uses a cross-country sample. In Medina and Schneider's (2018) article there is an estimated value of tax evasion from 158 countries in 2008-2015, a survey on tax evasion from the IMD World Competitiveness Yearbook only covers 62 countries, while the WEF Global Competitiveness Report covers 134 countries. In addition, this study excludes two countries because of incomplete data and economic conditions that are currently unstable because it is feared to produce biased estimates. Thus, the country sample used in this study is 132 countries for the dependent variable TEVA1 and 62 countries for the dependent variable TEVA2.

Data obtained from various sources. Data on tax evasion was obtained from Medina and Schneider (2018) and the IMD World Competitiveness Yearbook. The WEF Global Competitiveness Report provides data on strength of audit and reporting 
standards (SARS), market size (MKTS), and tax rate (TAXR). Data on corruption (CORR) was obtained from Transparency International. Data on the unemployment rate was obtained from the International Labor Organization. Data on GDP per capita (GDPC) and tax complexity (COMP) are obtained from the World Bank. The result, for the final sample of this study found 985 country-year observations for the TEVA1 dependent variable model, and 455 country-year observations for the TEVA1 dependent variable model.

This study uses two measurements for tax evasion. The first measurement is using a macro approach (TEVA1) by using the shadow economy based on the econometric calculations of the MIMIC approach model from Schneider (2000). With a measurement scale of $\%$ of GDP. The second measurement is using a micro approach (TEVA2) by using a survey of state tax evasion (a scale from $0=\operatorname{tax}$ evasion often, up to $10=$ rare), then this variable is transformed by reducing the country's survey ranking from 10 to get a scale of embezzlement increase tax. In addition, the use of two embezzlement measurements is an attempt to test robustness in the model.

For the independent variable, this study examines the strength of audit and reporting standards (SARS) and corruption (CORR). Strength of audit and reporting standards (SARS) are measured from surveys that ask leading business executives with the following questions: "In your country, how strong are the auditing and financial reporting standards?" by using a scale from 1 to 7 , where $1=$ very weak, $7=$ very strong. Corruption (CORR) is measured using the Corruption Perception Index (CPI), which is a perception of the level of corruption in the public sector according to experts and entrepreneurs. CPI is between 0 and 100, the greater the CPI value, the most probable it is from corruption. Then, the result of the CPI is transformed into a dummy variable where it is 1 if the country sample is above the average value, and 0 otherwise. For the definitions of variables used in this study see Appendix 1.

To test hypothesis 1 and hypothesis 2, this study uses multiple linear regression analysis with the ordinary least square (OLS) method. OLS is a linear regression model with the least squares calculation method. In this research the model also includes several control variables based on previous researches. The details of the research model used are as follows:

$$
\begin{aligned}
\text { TEVA }_{i t}=\alpha+ & \beta_{1} \text { SARS }_{i t}+\beta_{2} \text { CORR }_{i t}+\beta_{3} \text { MKTS }_{i t}+\beta_{4} G_{D P C}+\beta_{5} U N M P_{i t} \\
& +\beta_{6} \text { TAXR }_{i t}+\beta_{7} \operatorname{COMP}_{i t}+\varepsilon
\end{aligned}
$$

To test hypothesis 3 , the study uses path analysis with the multilevel mediation models method (1-1-1). Path analysis is used because this research is faced with a model where the dependent variable causes other dependent variables. Path analysis can also be seen as SEM (Structural Equation Modeling) where path analysis is a kind of SEM which has only one indicator, or a structural model of SEM analysis. The difference is that path analysis only analyzes construct variables, whereas in 
SEM all variables both indicator variables and construct variables are analyzed together in one model. The path analysis model that this research uses is as in Figure 1 .

Figure 1. Path analysis of the research

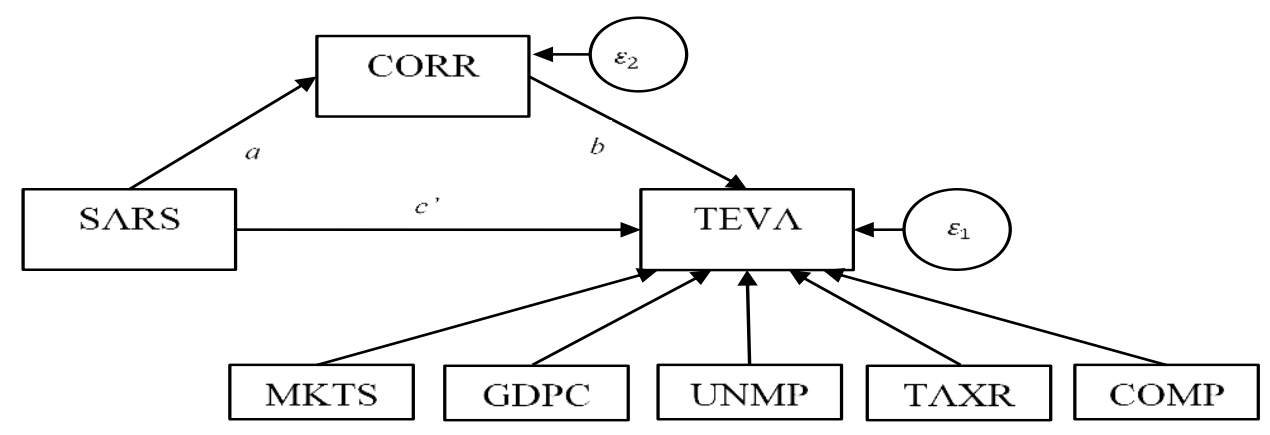

Source: Authors.

\section{Results}

Table 1 presents descriptive statistics of the variables used in this study. For the dependent variable, tax evasion TEVA1 has an average of 26.61 percent with range values from 6.16 to 58.67 percent, while TEVA2 has an average of 5.6 with range values from 0.98 to 9.3 . Strength of audit and reporting standards have an average of 4.68 with range values from 2.2 to 6.7 . Corruption is a dummy variable with an average of 0.39 .

Table 1. Descriptive statistics

\begin{tabular}{|c|c|c|c|c|}
\hline Variable & Mean & Min & Max & Std. Deviation \\
\hline TEVA1 & 26.61277 & 6.16 & 58.67 & 11.56668 \\
\hline TEVA2 & 5.606 & 0.98 & 9.3 & 1.758021 \\
\hline SARS & 4.683249 & 2.2 & 6.7 & 0.8515968 \\
\hline CORR & 0.3969543 & 0 & 1 & 0.4895149 \\
\hline MKTS & 3.681218 & 1 & 7 & 1.188513 \\
\hline GDPC & 16284.69 & 128.5 & 120449.5 & 21157.34 \\
\hline UNMP & 7.472619 & 0.16 & 28.01 & 5.29145 \\
\hline TAXR & 44.44792 & 9.6 & 292.4 & 29.85908 \\
\hline COMP & 292.0376 & 12 & 2600 & 283.0362 \\
\hline
\end{tabular}

Note: This table presents the descriptive statistical results of the research variables used in this study. This study used a sample of 132 countries from 2008-2015 with a total sample of 985.

Source: Authors. 
Table 2 presents the results of multivariate analysis using the ordinary least square (OLS) method. By using the dependent variable TEVA1, this study found that strength of audit and reporting standards negatively and significantly affect tax evasion with a significance level of $1 \%$ (Coeff $=-1.100104 ; \mathrm{t}=-2.61)$. Corruption negatively and significantly affects tax evasion with a significance level of $1 \%$ (Coeff $=-7.464301 ; \mathrm{t}=-10.09$ ). This study also uses the dependent variable TEVA2 as an alternative proxy for measuring tax evasion, found that strength of audit and reporting standards negatively and significantly affect tax evasion with a significance level of $1 \%$ (Coeff $=-0.9670896 ; t=-8.73)$. Corruption negatively and significantly affects tax evasion with a significance level of $1 \%$ (Coeff $=$ $0.4780507 ; \mathrm{t}=-2.82$ ). In general, the results of both models support hypothesis 1 and hypothesis 2 of this study.

The overall explanatory power of the model with the dependent TEVA1 variable is significantly high with a value of $\mathrm{F}=190.30$ and an adjusted R-Squared value of 0.5769 , in addition, a maximum variance inflation factor (VIF) value of 2.27 which indicates no multicollinearity problem. In the model with TEVA2 dependent variable is significantly high with a value of $F=69.83$ and adjusted $R$-Squared value of 0.5223 , with a maximum VIF value of 1.96 .

This result implies that strengthening audit quality and reporting standards and reducing the level of corruption can help government efforts to reduce tax evasion. Good audit and reporting quality makes it possible for companies to fear tax evasion because of the high possibility of detection, while good quality reporting standards make financial statements difficult to manipulate. In addition, eliminating corruption can reduce tax evasion by eliminating bribery practices from corrupted officials who facilitate companies to manipulate.

Table 2. Regression results from strength of audit \& reporting standards and corruption on tax evasion

\begin{tabular}{|l|c|c|}
\hline \multirow{2}{*}{ VARIABLES } & \multicolumn{3}{|c|}{ Dependent Variable: Tax Evasion } \\
\cline { 2 - 3 } & TEVA1 (1) & TEVA2 (2) \\
\hline SARS & $-1.100104^{* * *}$ & $-0.9670896^{* * *}$ \\
& $(-2.61)$ & $(-8.73)$ \\
\hline CORR & $-7.464301^{* * *}$ & $-0.4780507^{* * *}$ \\
& $(-10.09)$ & $(-2.82)$ \\
\hline MKTS & $-2.240155^{* * *}$ & $-0.1943036^{* * *}$ \\
& $(-10.05)$ & $(-2.96)$ \\
\hline GDPC & $-0.0001675^{* * *}$ & $-0.0000134^{* * *}$ \\
& $(-9.96)$ & $(-4.15)$ \\
\hline UNMP & $-0.2115915^{* * *}$ & $0.0525511^{* * *}$ \\
& $(-4.55)$ & $(4.16)$ \\
\hline TAXR & 0.0134013 & $0.0215348^{* * *}$ \\
& $(1.61)$ & $(5.21)$ \\
\hline
\end{tabular}




\begin{tabular}{|l|c|c|}
\hline COMP & $\begin{array}{c}0.0024707^{* * * *} \\
(2.61)\end{array}$ & $\begin{array}{c}-0.0002003 \\
(-1.08)\end{array}$ \\
\hline CONSTANTA & $\begin{array}{c}45.96673^{* * *} \\
(24.16)\end{array}$ & $\begin{array}{c}10.91392^{* * *} \\
(17.59)\end{array}$ \\
\hline $\begin{array}{l}\text { Number of } \\
\text { Observation }\end{array}$ & 985 & 455 \\
\hline R-Squared & 0.5769 & 0.5223 \\
\hline Max VIF & 2.27 & 1.96 \\
\hline
\end{tabular}

Note: This table presents the regression results from the power of audits \& reporting standards and corruption on tax evasion. *, **, and *** are significant in $10 \%, 5 \%$ and $1 \%$ respectively.

Source: Authors.

Table 3 presents the results of the effects of corruption mediation on the effect of strength of audit and reporting standards on tax evasion using the multilevel mediation analysis method. By using the dependent variable TEVA1 and corruption as mediating variables, this study found that there was an indirect effect $\left(a^{*} b\right)$ on the effect of strength of audit and reporting standards on negative and significant tax evasion at the $1 \%$ level (path coeff $=-0.210$ ). Using the dependent variable TEVA2, this study found that there is an indirect effect $\left(a^{*} b\right)$ on the effect of strength of audit and reporting standards on negative and significant tax evasion at the 5\% level (path coeff $=-0.076$ ). In general, the results of both models support hypothesis 3 of this study.

The overall explanatory power in the path analysis model with the TEVA1 dependent variable was significantly high with an SRMR value of 0.052 and an Rsquared adjusted value of 0.574 . In the path analysis model with TEVA2 dependent variables, the SRMR value is 0.052 and the R-squared adjusted value is 0.574 . Overall the two models can be said to be feasible.

Table 3. Results of Corruption Mediation Effects on the Effects of Strength of audit \& Reporting Standards on Tax Evasion

\begin{tabular}{|l|c|c|}
\hline \multicolumn{1}{|c|}{ Path Coefficient } & \multicolumn{2}{c|}{ Dependent Variable } \\
\cline { 2 - 3 } & TEVA1 (1) & TEVA2 (2) \\
\hline Direct effect $\left(c^{\prime}\right)$ & $-0.081^{* * *}$ & $-0.387^{* * *}$ \\
& $(0.030)$ & $(0.052)$ \\
\hline Indirect effect $\left(a^{*} b\right)$ & $-0.210^{* * *}$ & $-0.076^{* *}$ \\
& $(0.022)$ & $(0.029)$ \\
\hline Total effect $\left(c^{\prime}+a^{*} b\right)$ & $-0.291^{* * *}$ & $-0.463^{* * *}$ \\
& $(0.028)$ & $(0.045)$ \\
\hline Path $a: \boldsymbol{C O R R}_{\boldsymbol{i t}} \leftarrow \boldsymbol{S A R S}_{\boldsymbol{i t}}$ & & \\
SARS & $0.665^{* * *}$ & $0.589^{* * *}$ \\
& $(0.017)$ & $(0.033)$ \\
\hline Path $b: \boldsymbol{T E V A}_{\boldsymbol{i t}} \leftarrow \boldsymbol{C O R R}_{\boldsymbol{i t}}$ & & \\
CORR & $-0.316^{* * *}$ & $-0.129 * * *$ \\
\hline
\end{tabular}




\begin{tabular}{|l|c|c|}
\hline & $(0.031)$ & $(0.047)$ \\
\hline Control Variable: $\boldsymbol{T E V} \boldsymbol{A}_{\boldsymbol{i t}} \leftarrow \boldsymbol{X}_{\boldsymbol{i t}}$ & & \\
MKTS & $-0.230^{* * *}$ & $-0.109 * * *$ \\
& $(0.024)$ & $(0.035)$ \\
\hline GDPC & $-0.306^{* * *}$ & $-0.183^{* * *}$ \\
& $(0.022)$ & $(0.045)$ \\
\hline UNMP & $-0.096^{* * *}$ & $0.143 * * *$ \\
& $(0.020)$ & $(0.035)$ \\
\hline TAXR & $0.034 *$ & $0.207 * * *$ \\
& $(0.018)$ & $(0.039)$ \\
\hline COMP & $0.060^{* * *}$ & -0.039 \\
& $(0.023)$ & $(0.037)$ \\
\hline Number of Observation & 985 & 455 \\
\hline R-Squared Adjusted & 0.574 & 0.515 \\
\hline SRMR & 0.052 & 0.067 \\
\hline NFI & 0.908 & 0.897 \\
\hline Chi-Square & 235.335 & 113.000 \\
\hline
\end{tabular}

Note: This table presents the results of the path analysis of the power of audits \& reporting standards, corruption and tax evasion. Using Multilevel Mediation Models (1-1-1). Bootstrap results for indirect effects based on 500 simulations. *, **, and *** are significant in $10 \%, 5 \%$ and $1 \%$ respectively.

Source: Authors.

Furthermore, this study found that the indirect effect of the effect of strength of audit and reporting standards on tax evasion is greater than the direct effect. The path coefficient of the indirect effect $\left(a^{*} b\right)$ shows the value of -0.210 and the path coefficient of the direct effect $\left(c^{\prime}\right)$ of -0.081 . This result implies that to reduce tax evasion the government must reduce the level of corruption in advance through strengthening audits and reporting standards.

\section{Conclusion}

The study provides a clearer view of how the influence of strength of audit and reporting standards abd corruption on tax evasion. The results showed that there was a negative influence on the strength of audits and reporting standards and corruption on tax evasion. This result implies that strengthening audit quality and reporting standards and reducing the level of corruption can help government's efforts to reduce tax evasion. Good audit and reporting quality makes it possible for companies to fear tax evasion because of the high possibility of detection, while good reporting quality makes financial reports difficult to manipulate. In addition, eliminating corruption can reduce tax evasion by eliminating bribery practices from corrupt officials who facilitate companies to manipulate.

In addition, this study shows that corruption mediates the effect of strength of audit reporting standards on tax evasion. This implies that in order to reduce tax evasion, 
the government must reduce the level of corruption in advance through strengthening audits and reporting standards. Law enforcement policies such as policies to strengthen audits and reporting standards can be a means to reduce corruption by increasing transparency thereby increasing the risk of detection of corrupted officials when they want to bribe. In the end, it is hoped that no more corrupt officials will facilitate the company to manipulate financial statements.

This study also has several limitations. First, until now there has been no tax evasion indicator that shows the actual condition, so further research need a recent measurement of tax evasion that can show the actual condition. Second, the problem in panel data analysis with cross-country samples usually lies in incomplete data, but this study seeks to obtain more samples so that the research results are not biased, therefore we use a few control variables even though there are other important variables that can be affect tax evasion as for example culture.

\section{References:}

Alm, J., Martinez-Vazquez, J., McClellan, C. 2016. Corruption and firm tax evasion. Journal of Economic Behavior and Organization, 124, 146-163.

Alm, J., Yunus, M. 2009. Spatiality and persistence in U.S. individual income tax compliance. National Tax Journal, 62(1), 101-124.

Amara, I., Khlif, H. 2018. Financial crime, corruption and tax evasion: a cross-country investigation. Journal of Money Laundering Control, 21(4), 545-554.

Amoh, J.K., Ali-Nakyea, A. 2019. Does corruption cause tax evasion? Evidence from an emerging economy. Journal of Money Laundering Control, 22(2), 217-232.

Auerbach, A., Bandiera, O., Blundell, R., Chetty, R., Gentry, W., Kopczuk, W., Singhal, M., Slemrod, J. 2011. Unwilling or Unable to Cheat? Evidence From a Tax Audit Experiment in Denmark. Econometrica, 79(3), 651-692.

Brasoveanu, I., Brasoveanu, L. 2009. Correlation between Corruption and Tax Revenues in EU27. Economic Computation and Economic Cybernetics Studies and Research / Academy of Economic Studies, 43, 133-142.

Cebula, R.J. 1997. An empirical analysis of the impact of government tax and auditing policies on the size of the underground economy: The case of the United States, 1973-94. American Journal of Economics and Sociology, 56(2), 173-185.

D’Agosto, E., Manzo, M., Pisani, S., D’Arcangelo, F.M. 2018. The Effect of Audit Activity on Tax Declaration: Evidence on Small Businesses in Italy. Public Finance Review, 46(1), 29-57

Debacker, J., Heim, B.T., Tran, A., Yuskavage, A. 2018. Once bitten, twice shy? The lasting impact of enforcement on tax compliance. Journal of Law and Economics, 61(1), 1 35 .

Dreher, A., Kotsogiannis, C., McCorriston, S. 2009. How do institutions affect corruption and the shadow economy? International Tax and Public Finance, 16(6), 773-796.

Dreher, A., Schneider, F. 2010. Corruption and the shadow economy: An empirical analysis. Public Choice, 144(1), 215-238.

Ghura, D. 1998. Tax Revenue in Sub-Saharan Africa: Effects of Economic Policies and Corruption. In IMF Working Papers, 98(135).

Goel, R.K., Saunoris, J.W. 2014. Global corruption and the shadow economy: Spatial aspects. Public Choice, 161(1-2), 119-139. 
Houqe, N., Monem, R.M. 2013. Corruption, Political Institutions, and Accounting Environment: A Cross-Country Study. SSRN Electronic Journal, 17(1), 1-35.

Khlif, H., Guidara, A. 2018. Quality of management schools, strength of auditing and reporting standards and tax evasion: A cross-country analysis. EuroMed Journal of Business, 13(2), 149-162.

Khlif, H., Guidara, A., Hussainey, K. 2016. Sustainability level, corruption and tax evasion: A cross-country analysis. Journal of Financial Crime, 23(2), 328-348.

Kimbro, M.B. 2002. A Cross-Country Empirical Investigation of Corruption and its Relationship to Economic, Cultural, and Monitoring Institutions: An Examination of the Role of Accounting and Financial Statements Quality. Journal of Accounting, Auditing and Finance, 17(4), 325-350.

Malagueño, R., Albrecht, C., Ainge, C., Stephens, N. 2010. Accounting and corruption: a cross-country analysis. Journal of Money Laundering Control, 13(4), 372-393.

Maria, A., Nasca, A. 2018. The Strength of Auditing and Reporting Standards in Relation to Financial. SEA, Practical Application of Science, VI(17), 193-197.

Medina, L., Schneider, F. 2018. Shadow Economies Around the World: What Did We Learn Over the Last 20 Years? In Working Paper No. 18/17.

Paseková, M., Kramná, E., Svitáková, B., Dolejšová, M. 2019. Relationship between legislation and accounting errors from the point of view of business representatives in the Czech Republic. Oeconomia Copernicana, 10(1), 193-210. doi: 10.24136/oc.2019.010.

Picur, R.D., Riahi-Belkaoui, A. 2006. The impact of bureaucracy, corruption and tax compliance. Review of Accounting and Finance, 5(2), 174-180.

Richardson, G. 2008. The relationship between culture and tax evasion across countries: Additional evidence and extensions. Journal of International Accounting, Auditing and Taxation, 17(2), 67-78.

Rupeika-Apoga, R., Zaidi, H.S., Thalassinos, E.Y., Thalassinos, I.E. 2018. Bank Stability: The Case of Nordic and Non-Nordic Banks in Latvia. International Journal of Economics and Business Administration, 6(2), 39-55, DOI: 10.35808/ijeba/156.

Smith, K.W., Stalans, L.J. 1994. Negotiating Strategies for Tax Disputes: Preferences of Taxpayers and Auditors. Law and Social Inquiry, 19(2), 337-368.

Schneider, F. 2000. Dimensions of the Shadow Economy. The Independent Review, 5(1), 81-91.

Strîmbu, O., González, P. 2018. Does transparency reduce political corruption? Journal of Public Economic Theory, 20(2), 123-135.

Suryanto, T., Thalassinos, E.Y., Thalassinos, I.E. 2017. Board Characteristics, Audit Committee and Audit Quality: The Case of Indonesia. International Journal of Economics and Business Administration 5 (3), 47-57.

Suryanto, T., Thalassinos, I.E. 2017. Cultural Ethics and Consequences in Whistle-Blowing among Professional Accountants: An Empirical Analysis. Journal of Applied Economic Sciences, 6(52), 1725-1731.

Torgler, B., Schneider, F. 2007. Shadow Economy, Institutions, and Tax Morale. The National Tax Journal, 27(4), 515-530.

Vokshi, N.B. 2018. The connection between accounting and taxation from the perspective of preparing the financial statements. International Journal of Economics and Business Administration, 6(4), 34-47.

Wu, X. 2005. Firm Accounting Practices, Accounting Reform and Corruption in Asia. Policy and Society, 24(3), 53-78. 
Appendix 1. Variable Definitions

\begin{tabular}{|c|c|c|}
\hline Variable & Description & Data Source \\
\hline \multicolumn{3}{|c|}{ Dependent Variable } \\
\hline $\begin{array}{l}\text { Tax Evasion } \\
\text { (TEVA1) }\end{array}$ & $\begin{array}{l}\text { TEVA1 is measured using shadow economy based on } \\
\text { the econometric calculation of the MIMIC model } \\
\text { approach. With a measurement scale of \% of GDP. The } \\
\text { sample uses } 132 \text { countries from } 2008-2015 \text {. }\end{array}$ & $\begin{array}{l}\text { Medina and } \\
\text { Schneider (2018) }\end{array}$ \\
\hline $\begin{array}{l}\text { Tax Evasion } \\
\text { (TEVA2) }\end{array}$ & $\begin{array}{l}\text { TEVA2 is measured from a survey of state tax evasion } \\
\text { (scale from } 0=\text { tax evasion often, up to } 10=\text { rare), the } \\
\text { sample used } 62 \text { countries from } 2008-2015 \text {. This variable } \\
\text { is transformed by reducing the country's survey ranking } \\
\text { from } 10 \text { to get the scale of increasing tax evasion. }\end{array}$ & $\begin{array}{l}\text { IMD World } \\
\text { Competitiveness } \\
\text { Yearbook }\end{array}$ \\
\hline \multicolumn{3}{|c|}{ Independent Variable } \\
\hline $\begin{array}{l}\text { Strength of Audit } \\
\text { and Reporting } \\
\text { Standard (SARS) }\end{array}$ & $\begin{array}{l}\text { SARS is measured from surveys regarding strength of } \\
\text { audit and reporting standards. Using a scale from } 1 \text { to } 7 \text {, } \\
\text { where } 1=\text { very weak, } 7=\text { very strong. }\end{array}$ & $\begin{array}{l}\text { WEF Global } \\
\text { Competitiveness } \\
\text { Report }\end{array}$ \\
\hline $\begin{array}{l}\text { Corruption } \\
\text { (CORR) }\end{array}$ & $\begin{array}{l}\text { CORR is measured using the Corruption Perception } \\
\text { Index (CPI), which is a perception of the level of } \\
\text { corruption in the public sector according to experts and } \\
\text { entrepreneurs, the greater the value of the CPI, the } \\
\text { cleaner it is from corruption. Using a dummy scale } \\
\text { which is } 1 \text { if the country sample is above the average } \\
\text { CPI value, and } 0 \text { if otherwise. }\end{array}$ & $\begin{array}{l}\text { Transparency } \\
\text { International }\end{array}$ \\
\hline \multicolumn{3}{|l|}{ Control Variable } \\
\hline $\begin{array}{l}\text { Market Size } \\
\text { (MKTS) }\end{array}$ & $\begin{array}{l}\text { MKTS is measured by the amount of gross domestic } \\
\text { product plus the value of imported goods and services, } \\
\text { minus the value of exports of goods and services. With a } \\
\text { normalized measurement scale on a scale of } 1 \text { to } 7 \text {. }\end{array}$ & $\begin{array}{l}\text { WEF Global } \\
\text { Competitiveness } \\
\text { Report }\end{array}$ \\
\hline $\begin{array}{l}\text { GDP per Capita } \\
\text { (GDPC) }\end{array}$ & $\begin{array}{l}\text { GDPC is measured by gross domestic product divided } \\
\text { by midyear population. The measurement scale is } \\
\text { presented in US Dollars. }\end{array}$ & World Bank \\
\hline $\begin{array}{l}\text { Unemployment } \\
\text { (UNMP) }\end{array}$ & $\begin{array}{l}\text { UNMP is the percentage of the workforce that is not } \\
\text { working but is available for and looking for work. With } \\
\text { a measurement scale of } \% \text { of the total workforce. }\end{array}$ & $\begin{array}{l}\text { International } \\
\text { Labour } \\
\text { Organization (ILO) }\end{array}$ \\
\hline Tax Rate (TAXR) & $\begin{array}{l}\text { TAXR is the total tax of five types of taxes and } \\
\text { contributions paid after accounting for deductions and } \\
\text { exemptions: income tax or corporate income tax, social } \\
\text { contributions and labor taxes paid by the employer, } \\
\text { property tax, turnover tax and other small taxes. }\end{array}$ & $\begin{array}{l}\text { WEF Global } \\
\text { Competitiveness } \\
\text { Report }\end{array}$ \\
\hline $\begin{array}{l}\text { Complexity } \\
\text { (COMP) }\end{array}$ & $\begin{array}{l}\text { COMP is measured by the time it takes to prepare and } \\
\text { pay for three types of taxes and major contributions: } \\
\text { corporate income tax, value added tax or sales tax, and } \\
\text { labor taxes, including payroll taxes and social } \\
\text { contributions. With a measurement scale of hours per } \\
\text { year. }\end{array}$ & $\begin{array}{l}\text { World Bank, } \\
\text { Doing Business }\end{array}$ \\
\hline
\end{tabular}

